[2] Современные технологии и оборудование свеклосахарного производства. В двух частях. Часть $2 /$ В.О. Штангеев, В.Т Кобер, Л.Г. Белостоцкий, Н.И. Штангеева и др. - Киев: Цукор України, 2004. - 320 с.

[3] АC СССР № 1318834, кл. G 01 N 1/10, Устройство для заводки кристалла и отбора пробы из вакуум-аппаратов сахарного производства/В.В. Пименов, А.О. Полторак, Ю.М. Скаковский; заявитель Всесоюзный проектноконструкторский и научно-исследовательский институт автоматизации пищевой промышленности Научнопроизводственного объединения "Пищепромавтоматика" - Опубл.: 07.03.1992, Бюл. № 9,1992 г. - 5 с

[4] Скаковский Ю.М. Автоматизированная система управления технологическими потоками и производительностью сахарного завода [Текст]:/диссертация на соискание ученой степени кандидата технических наук: 05.13.07/ Ю.М. Скаковский.- Одесса, 1987.- 319 с.

\title{
References
}

[1] E. Zhukovskyj, Yu. Skakovskyj, V. Vytvyczkyj and A. Babkov, “Bagatorivneva ASUTP czukrovogo zavodu”, Dokl. 18 mizhnar. konf. z avtomatychnogo upravlinnya “AVTOMATYKA-2011” 28-30 veresnya 2011. Ukrayna: Lviv: Visnyk NU “Lvivska politexnika”, pp. 256-257, 2011

[2] Sovremennye tekhnologii i oborudovanie sveklosakharnogo proizvodstva. V dvukh chastyakh. Chast 2. V.O. Shtangeev, V.T Kober, L.G. Belostoczkij, N.I. Shtangeeva i dr. Kiev: Czukor Ukrayini, p. 320, 2004.

[3] AS SSSR № 1318834, kl. G 01 N 1/10, Ustrojstvo dlya zavodki kristalla i otbora proby iz vakuum-apparatov sakharnogo proizvodstva. V.V. Pimenov, A.O. Poltorak, Yu.M. Skakovskij; zayavitel Vsesoyuznyj proektnokonstruktorskij i nauchno-issledovatelskij institut avtomatizaczii pishhevoj promyshlennosti Nauchnoproizvodstvennogo obedineniya "Pishhepromavtomatika". Opubl.: 07.03.1992, Byul. № 9, p. 5, 1992.

[4] Yu. Skakovskij, Avtomatizirovannaya sistema upravleniya tekhnologicheskimi potokami i proizvoditelnostyu sakharnogo zavoda [Tekst]:/dissertacziya na soiskanie uchenoj stepeni kandidata tekhnicheskikh nauk: 05.13.07/ Yu.M. Skakovskij. Odessa, p. 319, 1987.

УДК 004.93

\section{ІНФОРМАЦІЙНА СИСТЕМА ДЛЯ ДОПОМОГИ ФІНАНСОВИМ УСТАНОВАМ У ВИЗНАЧЕННІ КРЕДИТОСПРОМОЖНОСТІ КЛІЕНТІВ}

\author{
Шпинковський О.А. ${ }^{1}$, Шпинковська M.І. ${ }^{2}$, Голобородько В.В. ${ }^{3}$ \\ 1,2,3 Одеський національний политехнічний університет, м. Одесса, Україна \\ ${ }^{1,2}$ K. т. н., доцент, ${ }^{3}$ бакалавр \\ ORCID: ${ }^{1}$ 0000-0002-7000-0327, ${ }^{2}$ 0000-0003-1679-6341 \\ E-mail: ${ }^{1}$ csonpu@ukr.net, ${ }^{2}$ mis-s@ukr.net
}

Copyright (C) 2018 by author and the journal “Automation technologies and business - processes. This work is licensed under the Creative Commons Attribution International License (CC BY). http://creativecommons.org/licanses/by/4.0

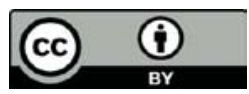

ONAFT

Open Access

DOI:

Анотація: У роботі підкреслено важливе місие у діяльності фінансових установ їх спроможність надавати якісні послуги юридччним та фізичним особам в отриманні кредитних позик. Розроблювальна інформаційна система надасть можсливість контролю роботи та керування записами користувачів системи. Завдяки ї̈ використанню банківські установи зможуть автоматизувати оцінку кредитоспроможності та уникнути небажаних ризиків та 
суб 'єктивних оцінок. Проаналізовано сучасні системи визначення можливості надання позик особам та організаціям. Визначено необхідні характеристики та фактори, щзо впливають на роботу систем. Запропоновано функціональні $і$ нефункиіональні вимоги до системи. Розроблено діаграми прецедентів, щзо надають повну інформацію зв'язку між користувачами та їх взаємодію з інформаційною системою. Спроектовано діаграми активності і послідовності, щзо надають інформацію про динамічні проиеси інформаційної системи. Розроблено діаграми зв'язків у таблицях баз даних, окреслено мінімальні необхідні вимоги до можливостей комп'ютера для функціонування додатку. Запропоновано алгоритми для оцінки кредитоспроможності клієнтів банку як юридичних так $і$ фізичних осіб.

Abstract: The paper emphasizes an important place in the activities of financial institutions, their ability to provide quality services to businesses and individuals in obtaining credit loans. The developed information system will provide the ability to monitor the work and manage the system user records. Thanks to its use, banking institutions will be able to automate a credit rating and avoid unwanted risks and subjective assessments. Analyzed the modern system of determining the possibility of providing loans to individuals and organizations. The necessary characteristics and factors affecting the operation of the systems were determined. Proposed functional and non-functional requirements. Developed use case diagrams, provide complete information of the communication between users and their interaction with the information system. The activity and sequence diagrams have been designed that provide information about the dynamic processes of the information system. Relationship diagrams in database tables have been developed, the minimum necessary requirements for a computer's capabilities for the operation of an application have been defined. Algorithms for assessing the creditworthiness of bank customers, both legal and natural persons, are proposed.

Ключові слова: інформаційна система, фінансова установа, кредитоспроможність, програмний продукт

Key words: information system, financial institution, creditworthiness, software product.

\section{Вступ}

Зараз, у вік технологій, що постійно вдосконалюються, допомогою у банківській справі стають інформаційні системи, що розробляються для банків та інших фінансових установ, та надають великий спектр можливостей для автоматизації операційною та проектною діяльністю, менеджменту, маркетингового позиціонування на фінансовому ринку [1]. Важливе місце у діяльності фінансових установ має їх спроможність надавати якісні послуги юридичним та фізичним особам в отриманні кредитних позик, управлінні та автоматизації процесами в оцінці кредитоспроможності, мінімізації ризиків непогашення кредиту.

На даний час банками розроблено велику кількість методів та способів оцінки кредитоспроможності свої клієнтів. Для забезпечення низького рівню ризику при видачі кредиту банківським установам необхідно розробляти максимально надійний алгоритм оцінки кредитоспроможності. У зв'язку з вищенаведеним, тема статті є актуальною.

\section{Аналіз літературних даних і постановка проблеми}

Проектування інформаційної системи.

Розробка програмного продукту для оцінки кредитоспроможності на даний час, із постійною зміною економічного становища та виникненням нових банківських установ, є дуже затребуваною справою. На сьогодні, та вже довгий час, затребувано розробляти програмні продукти, що прискорять роботу працівників у банківських установах, та знімуть певну відповідальність за суб’єктивну оцінку працівника при оцінці кредитоспроможності позичальника [1-2].

Хоча й досі в теорії та практиці немає єдиного підходу до визначення системи показників, які б комплексно характеризували кредитоспроможність позичальника - як клієнта, так і банківської установи. На протязі останніх років допомогою у банківській справі стають інформаційні системи, що розробляються для кредитних установ та дають великий спектр можливостей в оцінці кредитоспроможності, автоматизують процес оцінки та мінімізують ризик непогашення кредитів [1-2]

Незважаючи на розвиток сучасних технологій, інформація про банківські програми майже не розповсюджується. Запропоновано до розгляду два додатки для операційної системи Windows, які не є безкоштовними [1]:

- аналітичну систему «Audit expert»;

- фінансову аналітичну систему «ФінЕкАналіз».

Сформульовано, що запропонована інформаційна система, повинна увібрати в себе певні можливості аналогів та покращити їх. Додаток повинен мати функції багатокористувацької системи для розподілення можливостей працівників банку та їх керівників. Скориговано функції розроблюваної системи:

- інформаційна система повинна забезпечити можливість оцінки кредитоспроможності позичальників, як фізичних, так і юридичних осіб і бути вільно розповсюдженою;

- система повинна надавати можливість контролю облікових записів клієнтів та забезпечувати засоби адміністрування над працівниками, які з нею працюють. Цільовою аудиторією інформаційної системи $є$ насамперед банківські установи, тобто їх працівники, що будуть працювати у середовищі програми, та адміністратори банку, що зможуть керувати обліковими записами працівників.

Розглядається завдання прогнозування успіху маркетингової акції фінансової установи [3]. Основна мета - досягти збільшення обсягу та якості послуг, що надаються клієнтам, з визначенням цільової групи користувачів послуг, яким 
надаватимуться маркетингові пропозиції засобами соціальних мереж, е-mail розсилками, телефонуванням тощо. Для створення і навчання моделі, що класифікуватиме клієнтів на «отримувачів» і «не отримувачів» маркетингових пропозицій, використовуються дані декількох тисяч користувачів послуг, які складаються 320 категоріальних і числових ознак. Запропоновано заходи з оптимізації ознак для попереднього розрахунку ефективності маркетингової компанії, що хоча і опосередковано, але пов’язане з темою роботи що пропонується.

Метою наступної статті $є$ розробка алгоритму оцінки кредитною установою величини кредитного ліміту для фізичної особи-позичальника із урахуванням її соціально-демографічних характеристик за допомогою інструментарію логістичної регресії [4]. Зазначено що фінансові установи розраховують максимальну суму кредиту на підставі фінансових даних позичальника та його кредитної історії - чим краще фінансовий стан і платіжна дисципліна будьякого позичальника, тим більшу суму кредиту він може отримати.

Удосконалення процедури оцінки платоспроможності фізичної особи-позичальника полягає в інтеграції емпіричного підходу до визначення платоспроможності (на основі співвідношення офіційних доходів та витрат фізичної особи) з економіко-математичними методами, що дозволяють враховувати наявні ретроспективні дані фінансової установи про позичальників та виявляти статистично значущі закономірності. Ключову роль в алгоритмі оцінки кредитного ліміту займає розробка логіт-моделі для класифікації позичальників на класи «надійних» і «ненадійних», від класифікаційної сили якої буде значною мірою залежати прогнозна якість визначення суми кредитного ліміту. У роботі показано приклад застосування для кредитного скорингу логіт-моделі, що включає кількісні та якісні змінні, за допомогою яких описано соціально-демографічні характеристики позичальників. Проілюстровано порядок використання запропонованого алгоритму на підставі такої логіт-моделі. Загальноприйнятий підхід до вирішення цього завдання на поточний момент не вироблено.

Зазначено, що компаній, які пропонують послугу з отримання кредитів онлайн, з кожним роком на ринку стає все більше. Одні з них більш розрекламовані, інші — менш відомі. Офіційну статистику щодо їх загальної кількості навряд чи вдастся знайти. Припустити, що порядок цифр - десятки, якщо не сотні [5]. Наведено огляд 28 сервісів, які працюють на території України і в яких можна отримати кредит онлайн. Відмічено, що попри те, що кожен 3 них наголошує на своїй унікальності, при більш уважному аналізі можемо побачити, що у них більше спільного, аніж відмінного. Майже всі такі сервіси видають онлайн-кредити не більше ніж на 30 днів. Заявлена відсоткова ставка за перший кредит складає буквально 0\% або близько того. Як правило, вони не вимагають довідку про доходи, кредит готові оформити навіть без застави і поручителів. Наголошують, що ніяких прихованих платежів і комісій не нараховують. Саму заявку на кредит розглядають швидко i, у разі позитивного рішення, миттєво перекидають гроші на банківську картку позичальника [5]. Наявність великої кількості вищезазначених ресурсів не означає їх надійності, тривалої працеспроможності та якості послуг.

Також у мережі Інтернет є ресурси з інформацією фахівців банківських установ з теоретичними оглядами про механізми та особливості кредитування. Наприклад, надається інформація про скоринг-модель, як аналітичний інструмент, яким користуються більшість мікрофінансових компаній [6]. Сформульовано, що це комп’ютерна програма, яка працює за принципом відстеження та аналізу інформації з кредитної історії потенційного клієнта. За підсумком вивчення заявки клієнта, система кредитного скорингу видає результат у форматі загального бала. Зазначено, що високий бал кредитний скоринг забезпечує тим, у кого: високооплачувана робота, проживання у благополучному районі міста, наявність рухомого і нерухомого майна, вік від 25 до 38 років, наявність орендованої квартири й дітей, відсутність родичів, які потребують догляду, вища освіта, позитивні рішення 3 попередніх позик, відсутність інших непогашених заборгованостей. Зазначено, що відповідність цим параметрам допоможе заробити вищу оцінку, і як результат - зростають шанси на позитивне рішення за заявкою на позику.

3 вищеоглянутого можна зробити висновок, що хоча на даний час і розроблено достатню кількість методів та способів оцінки кредитоспроможності своїх клієнтів, не вистачає некоштовних інструментів універсального спрямування. Для забезпечення надійності, низького рівню ризику при видачі кредиту фінансовими установам необхідно розробляти максимально надійний та ефективний інструмент оцінки кредитоспроможності клієнтів.

\section{Мета і завдання роботи}

Метою роботи $є$ проектування інформаційної системи яка повинна забезпечити можливість оцінки кредитоспроможності позичальників, як фізичних, так і юридичних осіб. Система повинна надавати можливість контролю облікових записів клієнтів, надавати засоби адміністрування над працівниками, що використовують програму. Для досягнення мети треба:

3 урахуванням переваг та недоліків відомих розробок, спроектувати інформаційну систему, сформувати функціональні та нефункціональні вимоги до системи, розробити UML (Unified Modeling Language) діaграми компонентів системи та алгоритми для головних іï сценаріїв [7].

\section{Методи і матеріали розробки проекту}

Цільовою аудиторією інформаційної системи є насамперед банківські установи. А саме працівники банку, що будуть працювати у середовищі програми та адміністратори банку, що зможуть керувати обліковими записами працівників. 
Задачі які повинна вирішувати система:

1. Створення облікових записів адміністратора та працівників;

2. Контроль записів працівників та клієнтів;

3. Оцінка кредитоспроможності різних осіб;

4. Оцінка угоди з позичальником після отримання кредиту;

5. Зберігання інформації про клієнтів та працівників банку у мережі.

Інформаційні потоки системи: на вході інформація про клієнта, фізичну чи юридичну особу. На виході інформація про можливість отримати кредит та інформація про позичальників, які вже отримали кредит.

В інформаційній системі можливі два типи користувачів - це звичайний користувач додатку та адміністратор, що має змогу редагувати інформацію про користувача та надавати йому права адміністратора. Адміністратор має доступ до усіх можливостей звичайного користувача. Такий вибір типів користувачів зумовлений моделлю підпорядкування на виробництві, яка є обов'язковою.

Функціональні вимоги до системи: реєстрація, авторизація у додатку, оцінка кредитоспроможності фізичних, юридичних осіб, оцінка банківських угод, введення та обробка інформації про позичальника, підтримка можливостей керівництва системою.

Нефункціональні вимоги: інформаційна система має працювати з активним підключенням до інтернету, додаток має працювати на операційній системі Windows 7/8/10, система повинна зберігати дані про адміністраторів і користувачів в БД, додаток не повинен закриватися при наявності помилок, а вміти реагувати на них і сповіщати при цьому користувача.

Інформаційна система розроблятиметься для десктопних ком'ютерів 3 операційною системою Windows 3 можливістю проведення обчислень. Розроблювана система відноситься до типів Rich Client Application (RCA) i Calculating Application (CA) [8].

Уявлення компонентів (Components View).

Важливою частиною інформаційної системи $є$ зв’язок між іï компонентами та зовнішніми модулями та інструментами. Для візуалізації зв'язку між компонентами програми наведено діаграму компонентів (рис. 1).

Зовнішніми джерелами для системи є база даних та файли, що зберігаються для роботи нейронної мережі. У базі даних зберігаються дані про клієнтів та користувачів. А у допоміжних файлах нейронної мережі зберігається інформація про іiі навчання та тестування. Компоненти вікон та контролерів зв’язані напряму, без використання додаткових інтерфейсів.

Компонент NN Service відповідає за роботу нейронної мережі та безпосередньо пов'язаний із компонентом creditHelperIndividual, тому що саме при оцінці фізичних осіб буде використовуватись нейронна мережа. Компоненти Models зберігають усі моделі для передачі даних із форм.

Компонент, об'єкт доступу до даних DAO (data access object) є типічною сутністю бази даних [8]. За допомогою нього та компоненту Models у системі зберігається та використовується інформація бази даних. Компоненти CreditHelperIndividual, CreditHelperLegal призначені для проведення процедури оцінки кредитоспроможності фізичних та юридичних осіб відповідно. Компоненти Login та Registration відповідають за авторизацію та реєстрацію у системі. Компоненти IndividualRates та LegalRates виконують фунції генерації та виводу рейтингової таблиці із списку, отриманого від DAO сервісу. IndividualProfile та LegalProfile виконують фунцію виводу інформації про клієнтів фізичної або юридичної особи. Діаграма компонентів надає повну інформацію про модель інформаційної системи, зв'язків між ними та зовнішніми елементами.

Уявлення процесів (Process View).

В інформаційній системі застосовується багато різних алгоритмів роботи, але майже всі вони виконуються системою чи окремими бібліотеками. У розроблювальному програмному забезпеченні $є$ декілька алгоритмів, які мають найбільшу функціональну цінність і виділяють систему з ряду інших: оцінка кредитоспроможності фізичної, юридичної особи, авторизація. 


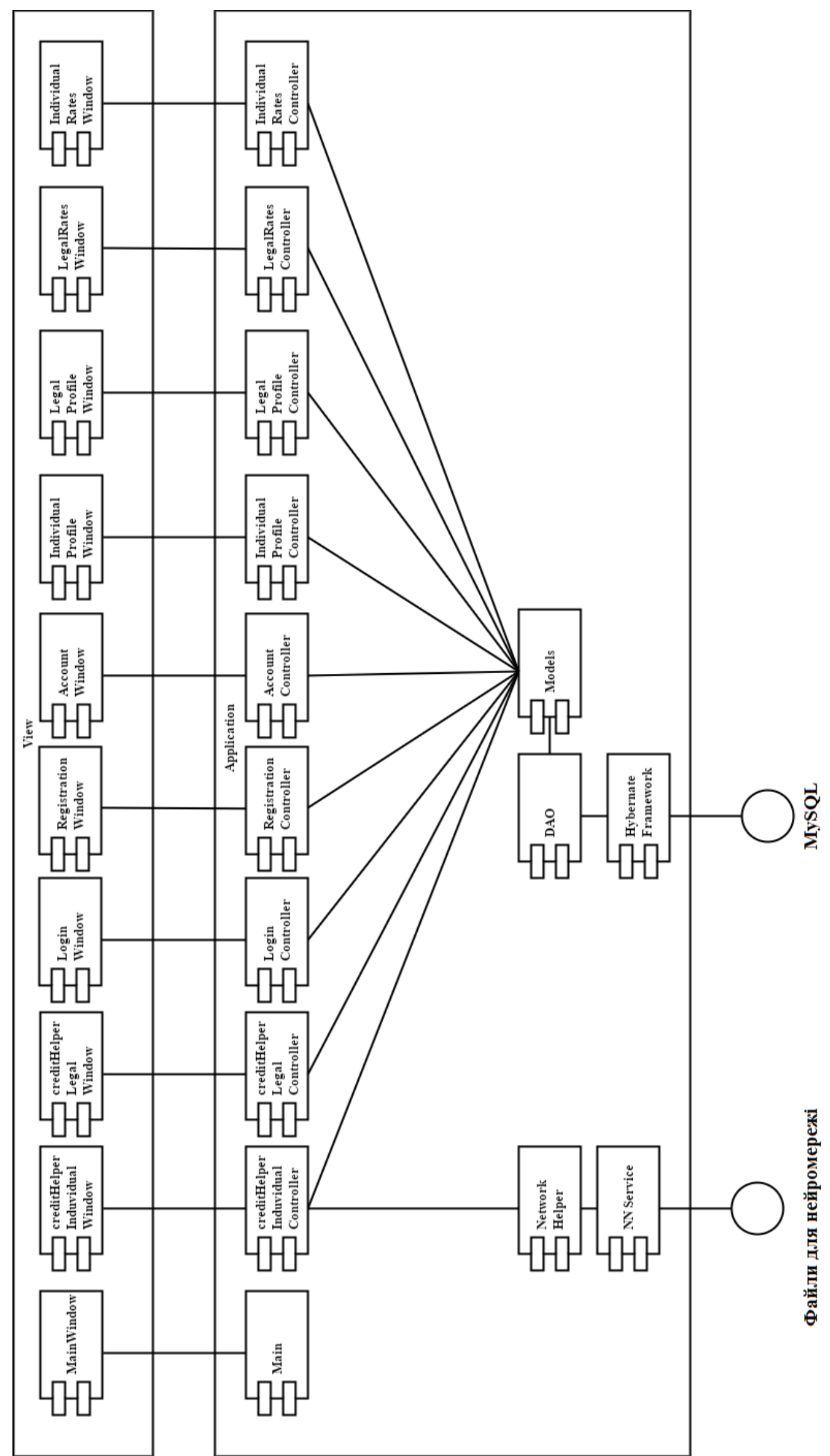

हैं

Пропонуються наступні основні сценарії системи: 
Сценарій 1. Для оцінки кредитоспроможності фізичної особи використовується наступний алгоритм, що складається з певних етапів. Спочатку заповнюється анкета клієнта відповідними даними. Після цього заповнюється форма фінансових показників клієнта. Дані, які зібрано, використовуються у розрахунках. За допомогою скорингових оцінок розраховується відповідна сума, що впливає на можливість отримати кредит. Фінансові показники також впливають на розрахунки оцінки кредитоспроможності, а саме беруться до уваги забезпечення клієнта, місячний прибуток та вимоги самого клієнта. За результатом усіх етапів можна отримати текстову відповідь про можливість отримання кредиту.

Сценарій 2. Ще одним із головних є алгоритм оцінки кредитоспроможності юридичної особи. Цей алгоритм прораховує можливість підприємства взяти кредит, а саме розрахунок ризику банку у видачі позики. По-перше, збираються загальні дані про підприємство, що ніяк не впливають на результат оцінки. На наступному етапі збираються дані про фінансове становище підприємства, потім дані про активи. Саме 3 цих даних розраховуються коефіцієнти рентабельності та ліквідності. На підставі отриманих, розраховується коефіцієнт ризику, за значенням якого можна обрати рівень ризику підприємства, тобто: без ризикове, підприємство, що складає деякий ризик та таке, що відповідає дуже ризиковому.

Сценарій 3. Перегляд кредитного рейтингу фізичних осіб теж є одним з головних сценаріїв програми. Користувач може отримати таблицю з кредитним рейтингом позичальників фізичних осіб, яка буде сформована за їх даними. В залежності від проходження оцінки, кожному позичальнику буде надано його диференційний бал, сформований із скорингової оцінки, що і буде впливати на місце позичальника у кредитному рейтингу.

Користувальницький інтерфейс (UI View).

Для наглядної візуалізації майбутнього додатку розроблено набір мокапів (mock-up) - спеціальних малюнків у вигляді файлів зображень для відпрацювання дизайну у реальних умовах співпраці з іншими додатками системи. На мокапах це відображається у вигляді іконок, які будуть використовуватись при побудові дизайну вже у середовищі розробки, на кшталт Eclipse [8]. Дизайн додатку виконаний у лаконічному та зрозумілому стилі. Весь користувальницький інтерфейс, як набір мокапів, зосереджується у діаграмі станів системи. На кожному мокапі, наприклад головному меню користувача, справа і зліва зображено номери інших вікон (станів системи), з якими його пов’язано (рис.2)

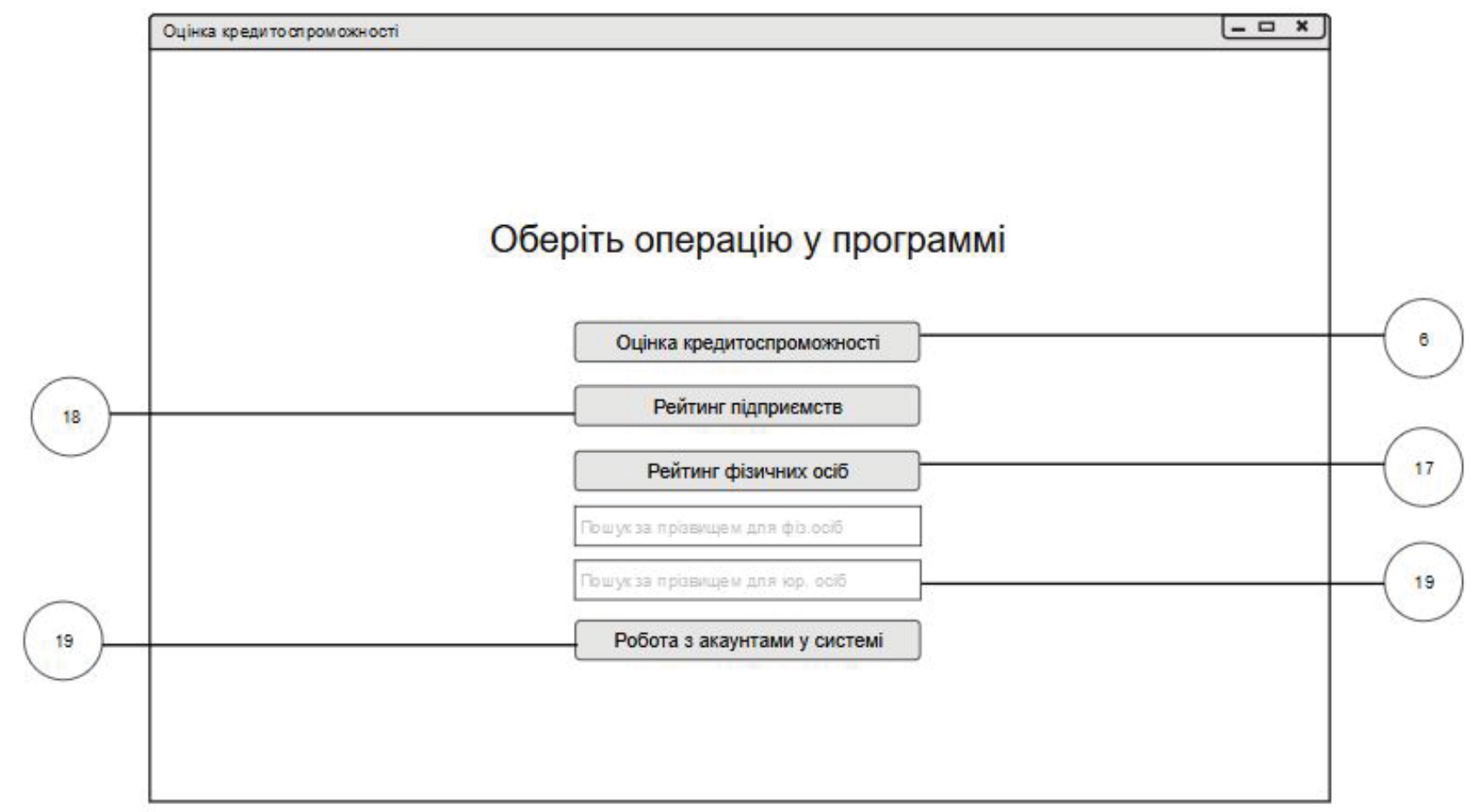

Рис.2 - Мокап головного меню програми для користувача

Уявлення даних (Data View).

Список класів, що потрібні для роботи з БД:

- $\quad$ LegalCreditModel (містить інформацію про кредити юридичних осіб);

- $\quad$ LegalModel (містить інформацію про юридичних осіб);

- $\quad$ IndividualModel (містить інформацію про фізичних осіб); 
- $\quad$ CreditModel (містить інформацію про кредити фізичних осіб);

- $\quad$ AccountModel (містить інформацію про користувачів системою).

Тип зберігання даних у системі - база MySQL. Доступ до неї надає Hibernate - засіб відображення між об'єктами та реляційними структурами (object-relational mapping, ORM) для платформи Java [8]. Hibernate $\epsilon$ вільним програмним забезпеченням, яке поширюється на умовах GNU Lesser General Public License. Hibernate надає легкий для використання каркас (фреймворк) для відображення між об'єктно-орієнтованою моделлю даних і традиційною реляційною базою даних [9]. Для роботи з базою даних будуть використовуватись додаткові класи DAO, що дозволить створювати, додавати, редагувати, записи у базі та встановлювати з нею безпосередній зв'язок.

Для наглядного представлення структури локальної бази даних побудовано схеми БД, які складаються з реляційної схеми для фізичних (рис. 3), юридичних осіб, а також для користувачів. У базі зберігається інформація про клієнтів. Може бути лише один клієнт з унікальним ідентифікатором. Він може мати безліч кредитів, тому він пов'язаний із сутністю як один до багатьох. Окрема таблиця, що зберігає ідентифікатори кредитів та клієнтів, створена завдяки логіки Hibernate.

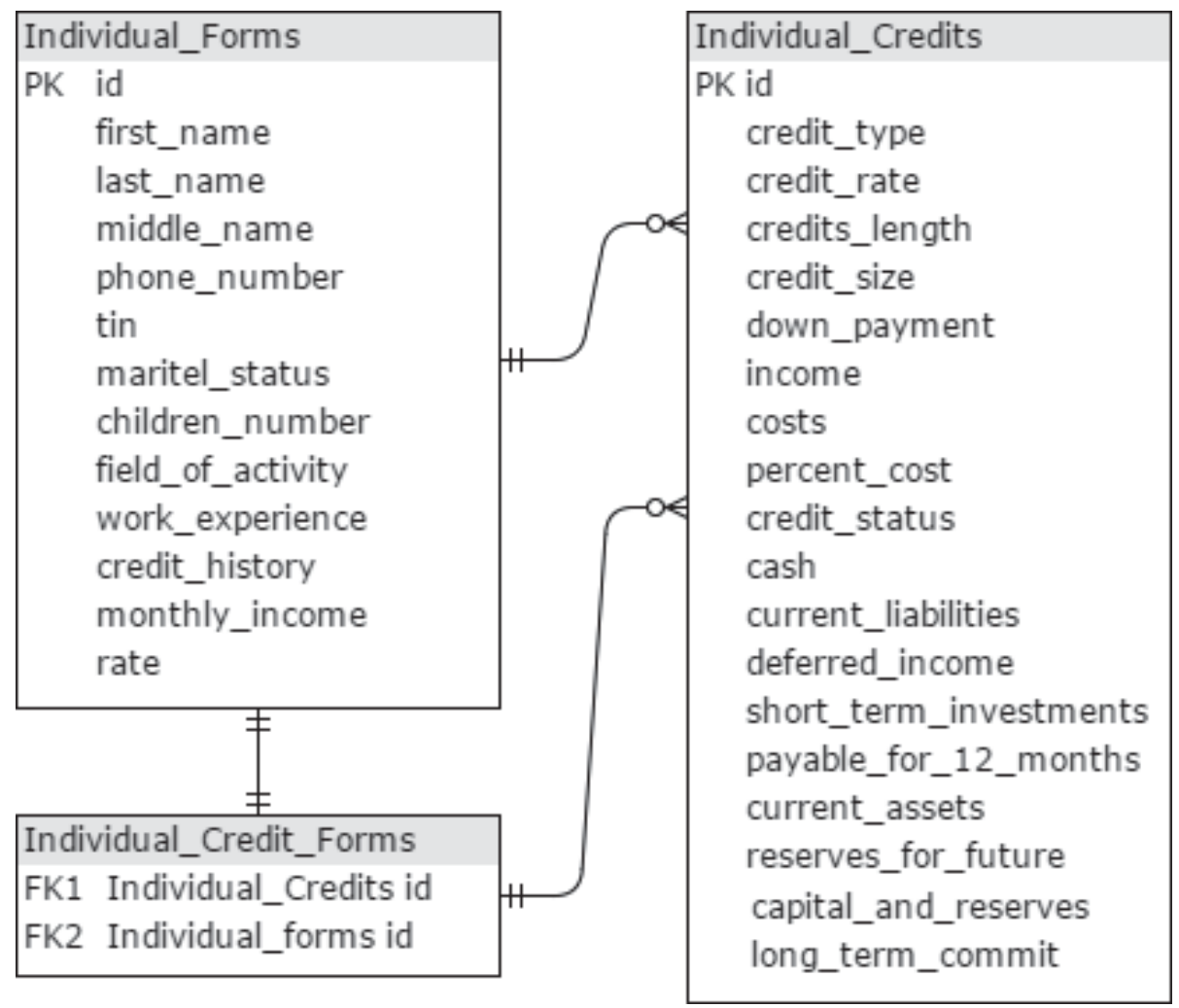

Рис. 3 - Реляційна схема бази даних таблиць фізичних осіб

Уявлення безпеки (Security View).

Безпека даних не $\epsilon$ ключовою в інформаційній системі, але теж повинна бути здійсненою на відповідному рівні. У системі реалізовано можливість ресстрації у системі. Це два типи користувачів: звичайний користувач (працівник банку) та користувач з надможливостями (керівник банку). Керівник банку має ті ж самі можливості, що і звичайний користувач та й ще можливість адмініструвати звичайних користувачів, редагувати їх дані, видаляти чи додавати до системи. Для усіх операцій з цими даними цих даних було створено БД на сервері, що зберігає усю інформацію про користувачів системи.

Вищезазначені бази про клієнтів та дані про них фізично розміщуватимуться на окремому сервері, доступ до якого отримати звичайному користувачу не вдасться. Для доступу до БД заплановано захищене підключення, завдяки якому система виходить на новий рівень безпеки.

Безпека бази даних реалізовано завдяки Hibernate. На програмному рівні реалізований рівень безпеки 3 підстановкою параметрів з мовою запитів (HQL), що захищає від можливих SQL-ін'єкцій.

Також для реалізації безпеки вирішено використовувати паролі для акаунтів не коротше за вісім символів. Це обміркована мінімальна довжина паролю, яку дуже складно розкрити. Було реалізовано хешування паролів MD5. Усі ці алгоритми гарантують достатню безпеку даних інформаційної системи.

Алгоритмічне представлення системи. 
Для системи розроблено два головних алгоритми, що відповідають за оцінку кредитоспроможності фізичних та юридичних осіб. Оцінки кредитоспроможності двох алгоритмів відрізняються. Роздивимось детальніше кожен 3 алгоритмів.

Алгоритм оцінки кредитоспроможності для фізичної особи.

На першому етапі вхідні дані для оцінки кредитоспроможності є наступними: ПІБ, контактний телефон, ІНН, вік, сімейний стан, кількість дітей, галузь діяльності, кваліфікація, стаж, середньомісячна заробітна плата, кредитна історія. ПІБ, контактний телефон та ІНН це суто загальні дані про клієнта, що не впливають на кінцеву оцінку.

По-перше, на результат оцінки впливає кредитна історія. Якщо клієнт у чорному списку банків, кредит такій особі видавати заборонено, тому це найризиковіша ситуація у видачі кредиту. Якщо кредитна історія чиста, тобто усі кредити своєчасно погашені, то клієнт розглядається як потенційний позичальник і може претендувати на отримання кредиту, якщо також задовольнить умовам інших оцінок. Якщо ж клієнт виплачує кредит у даний момент, то при прийнятті рішення буде враховуватись його забезпечення.

По-друге, інша інформація про клієнта буде використовуватись при скоринговому аналізі у нейронній мережі. Отримані дані будуть форматуватись у вигляді, 3 яким працює нейронна мережа і яка надасть відповідь про можливість надання кредиту за результатом аналізу.

На наступному етапі збираються і оцінюються дані про фінансове становище та умови кредиту. Якщо задані дані про фінансове становище задовольняють умовам кредиту, то клієнт може розраховувати на кредит.

Алгоритм оцінки кредитоспроможності для юридичної особи.

На першому етапі збирається загальна інформація про підприємство (юридичну особу), що не впливає на оцінку кредитоспроможності, та кредитна історія.

Аналогічно з оцінкою кредитної історії фізичної особи, якщо клієнт у чорному списку банків, Надання кредиту такій особі буде заборонено. Якщо кредитна історія чиста, тобто усі кредити своєчасно погашені, то клієнт розглядається як потенційний позичальник і може претендувати на отримання кредиту, якщо також задовольнить умови інших етапів оцінки. Якщо ж клієнт виплачує кредит у даний момент, то при видачі короткострокового кредиту буде враховуватись його забезпечення.

На наступному етапі також збираються дані про фінансове становище клієнта та умови кредитування. Якщо задані дані про фінансове становище задовольняють умовам кредиту, то клієнт може розраховувати на кредит.

На наступному етапі оцінюються активи та пасиви підприємства. Із наступних вхідних даних програма розраховує коефіцієнти ліквідності та рентабельності підприємства, що будуть впливати на виявлення групи ризику та остаточний результат оцінки кредитоспроможності.

Після усіх етапів, користувач системи отримає остаточну відповідь про можливість кредитування юридичної особи.

Інфраструктурне уявлення (Infrastructure View)

В інформаційній системі використовуються лише пристрої користувачів - персональні комп’ютери, ноутбуки.

Характеристики пристрою:

- $\quad$ 32-розрядний (х86) або 64-розрядний (х64) процесор з тактовою частотою 1 ГГц або вище;

- 1 ГБ (для 32-розрядної процесора) або 2 ГБ (для 64-розрядної процесора) ОЗУ;

- 16 ГБ (для 32-розрядної системи) або 20 ГБ (для 64-розрядної системи) вільного місця на жорсткому диску;

- графічний пристрій DirectX 9 д драйвером WDDM 1.0 або більш пізньої версії;

- операційна система Windows 7 або новіше;

- встановленний набір для роботи із Java додатками [9]. Це JDK для користувачів від компанії Оracle Corporation;

- активне підключення до інтернету.

Інші характеристики пристрою не впливають на роботу інформаційної системи. Додаток не потребує великих обчислювальних можливостей, тому його можна використовуватись на більшості комп’ютерів.

\section{Висновки}

У роботі було розкрито необхідність створення системи допомоги працівникам фінансових установ у наданні кредитів. Розглянуто аналоги подібних систем та виконано необхідні кроки Після етапу огляду технологій та аналогів було сформульовано вимоги до етапів проектування системи оцінки кредитоспроможності кліснтів банку. Розроблено діаграми прецедентів, що надають повну інформацію зв'язку між користувачами та їх взаємодію із інформаційною системою. Спроектовано діаграми активності і послідовності роботи головних процесів програми, що надають інформацію про динамічне представлення інформаційної системи. Також були розроблені діаграми зв'язків у таблицях БД, мінімальні необхідні вимоги до можливостей комп'ютера для функціонування додатку. Запропоновано алгоритми для оцінки кредитоспроможності клієнтів банку як юридичних так і фізичних осіб. У подальшому буде проведено практичне виконання програмного проекту з програмуванням, тестуванням модулів. 


\section{Список використаних джерел}

[1] Шпинковський О.А., Шпинковська М.І., Смельський Ю.С. Аналіз та рекомендації для створення інформаційних систем оцінки кредитоспроможності клієнтів банку // Науковий вісник Херсонського державного університету. Економічні науки. - 2017. - Вип. 27., Ч. 3. - Херсон: Видавничий дім «Гельветика»- С. 142-145.

[2] Шпинковський $\quad$ O.А., Шпинковська M.I., Система прогнозування виробничої діяльності та розвитку фермерського господарства / «Перспективні інновації в науці, освіті, виробництві та транспорті '2014» Январь 2014г [Електроний ресурс] Режим доступу: http://sworld.com.ua/index.php/ru/technical-sciences-413/informaticscomputer-science-and-automation-413/20865-413-1172

[3] Голобородько, В. В. Забезпечення ефективності маркетингових компаниій за допомогою машинного навчання / В. В. Голобородько, М. І. Шпинковська // Комп'ютерні інтелект. системи та мережі : ХII Всеукр. наук.-практ. WEB конф. аспірантів, студентів та молодих вчених : матеріали конф., 20-22 берез. 2019 р. / Кривор. нац. ун-т. Крівий Ріг, 2019. - С. 103-104.

[4] Ковпак Е. О., Туманова Ю. Г. Розрахунок кредитного ліміту для фізичної особи-позичальника на підставі логітмоделі // Бізнес Інформ. - 2018. - №12. - С. 162-169.

[5] 28 українських сервісів, де можна взяти кредит онлайн [Електронний ресурс]. Режим доступу: http://prybutok.com.ua/8047/kredyt-online/

[6] Кредитний скоринг - система оцінки кредитоспроможності позичальника: [Електронний ресурс]. Режим доступу: https://sravnizajm.com.ua/ua/blog/kreditnyy-skoring-sistema-otsenki-kreditosposobnosti-zayemshchika/

[7] Буч Г. Язык UML. Руководство пользователя / Г. Буч, Д. Рамбо, А. Джекобсон. - М.: ДМК, 2000. - 432 с.

[8] Гринфилд Джек. Фабрики разработки программ (Software Factories): потоковая сборка типовых приложений, моделирование, структуры / Джек Гринфилд. - «Диалектика», 2006.- 592 с.

[9] Бауэр, К. Java Persistence API и Hibernate : пер. с англ. / К. Бауэр, Г. Кинг, Г. Грегори. - 2-е изд. - Москва : ДМК Пресс, 2017. - 632 c.

\section{References}

[1] O. A. Shpinkovski, M. I. Shpinkovska and Y. S. Smelsky, Analysis and recommendations for the creation of information systems for assessing the creditworthiness of Bank's clients. Scientific Bulletin of the Kherson State University. Economic Sciences. - Issue. 27. Part. 3. Kherson: Publishing House "Helvetica" - P. 142-145, 2017.

[2] O. A. Shpinkovski and M. I. Shpinkovska, System of forecasting of production activity and development of a farm. "Promising innovations in science, education, production and transport" 2014.January 2014 [Electronic resource] Access mode: http://sworld.com.ua/index.php/en/technical-sciences-413/informatics-computer-science-and-automation413/20865-413-1172

[3] V. V. Goloborodko and M. I. Shpinkovska, Providing the effectiveness of marketing companies through machine learning. Computer Intellect. systems and networks: XII All ukr. sci. pract. Web conf. graduate students, students and young scientists: materials of the conference, 20-22 March. 2019. Krivy Rig: Krivor. nation. Univer. P. 103-104, 2019.

[4] E. O. Kovpak and Y. G. Tumanova, Calculation of the credit limit for the individual borrower on the basis of the logit model. Business Inform, №12. Pp. 162-169, 2018.

[5] 28 Ukrainian services, where you can take credit online [Electronic resource]. Access mode: http://prybutok.com.ua/8047/kredyt-online/

[6] Credit Scoring - The Borrower's Credit Rating System: [Electronic Resource]. Access mode: https://sravnizajm.com.ua/ru/blog/kreditnyy-skoring-sistema-otsenki-kreditosposobnosti-zayemshchika/

[7] G. Buch, D. Rambo and A. Jacobson The UML Language. User Guide. Moscow: DMK. P. 432, 2000.

[8] Greenfield Jack, Software Factories: Stream Generation of Typical Applications, Modeling, Structures. Dialectics. P. 52, 2006.

[9] K. Bauer, G. King and G. Gregory, Java Persistence API and Hibernate: per. from english. 2nd ed. Moscow: DMC Press. P. 632, 2017 